\title{
Achromatic optical retardation from perovskites
}

\author{
Daniela Täuber (iD ${ }^{1 凶}$
}

Nature Photonics 15, 813-816 (2021)

https://doi.org/10.1038/s41566-021-00865-0

Control of light polarization over a wide range of optical wavelengths is highly desirable within a variety of applications. Fabrication of 'waveplates' allowing for achromatic retardation usually requires a sophisticated combination of multiple layers of birefringent materials. A team of researchers from the School of Materials Science \& Engineering, the School of Physics and the School of Optics and Photonics at the Beijing Institute of Technology in China and from the Department of Chemistry at Princeton University in the United States, has found a very promising alternative approach using solutionprocessed ordered self-assembly of halide perovskites.
Such fabricated birefringent $\mathrm{Cs}_{4} \mathrm{PbBr}_{6}$ crystal interspersed with $\mathrm{CsPbr}_{3}$ nanocrystals showed good achromatic quarter-wave retardance over the spectral range of $532-800 \mathrm{~nm}$. Further work on self-assembled birefringent materials with embedded nanocrystals is expected to provide access to inexpensive high quality achromatic waveplates for a wide field of applications ranging from opto-electronics to biomedical diagnostics.

\section{Funding}

Open Access funding enabled and organized by Projekt DEAL.

Received: 1 September 2021 Accepted: 6 September 2021

Published online: 04 November 2021

Correspondence: Daniela Täuber (dantaube@gmx.de)

${ }^{1}$ Leibniz Institute of Photonic Technology, and Friedrich-Schiller University,

Abbe Center of Photonics and Institute of Physical Chemistry, Jena, Germany

(c) Open Access This article is licensed under a Creative Commons Attribution 4.0 International License, which permits use, sharing, adaptation, distribution and reproduction in any medium or format, as long as you give appropriate credit to the original author(s) and the source, provide a link to the Creative Commons license, and indicate if changes were made. The images or other third party material in this article are included in the article's Creative Commons license, unless indicated otherwise in a credit line to the material. If material is not included in the article's Creative Commons license and your intended use is not permitted by statutory regulation or exceeds the permitted use, you will need to obtain permission directly from the copyright holder. To view a copy of this license, visit http://creativecommons.org/licenses/by/4.0/. 